\title{
Variability and Trend Analysis of Temperature, Rainfall and Characteristics of Crop Growth Season in Eastern Zone of Tigray Region, Northern Ethiopia
}

Amdom Gebremedhin Berhe ( $\nabla$ amdomg@gmail.com )

Climate and society https://orcid.org/0000-0002-2617-1719

Solomon Habtu Misgna

Land Resource Management Environmental Protection

Girmay Gebre-Samuel Abraha

Land Resource Management Environmental Protection

Amanuel Zenebe Abraha

Climate and Society

\section{Research Article}

Keywords: temperature, rainfall , climatic variables, Tigray region, Northern Ethiopia

Posted Date: July 15th, 2021

DOl: https://doi.org/10.21203/rs.3.rs-474956/v2

License: (a) (1) This work is licensed under a Creative Commons Attribution 4.0 International License.

Read Full License 
Variability and trend analysis of temperature, rainfall and characteristics of crop growth season in Eastern zone of Tigray region, Northern Ethiopia

Amdom Gebremedhin Berhe ${ }^{1 *}$, Solomon Habtu Migna ${ }^{2}$, Girmay Gebre-Samuel Abraha ${ }^{3}$, Amanuel Zenebe Abraha ${ }^{1}$

Amdom Gebremedhin Berhe

*Correspondence: amdomg@gmail.com

ORCID (0000-0002-2617-1719)

Solomon Habtu Misgna

solomon.habtu@mu.edu.et

Girmay Gebre-Samuel Abraha

girmaygsamuel@gmail.com

Amanuel Zenebe Abraha

amanuelzenebe@gmail.com

${ }^{1}$ Institute of Climate and Society (ICS), Mekelle University (MU), Ethiopia

${ }^{2}$ Land Resource Management Environmental Protection (LaRMEP), MU, Ethiopia

${ }^{3}$ LaRMEP, MU, Ethiopia.

\begin{abstract}
To favour farmers and adjusting their farming practices, long term weather analyses is essential to determine future directions and making adjustments required to existing systems. The main purpose of this study was thus to analyze the variability and trends of climatic variables (temperature and rainfall) and characteristics of crop growth season in Eastern zone of Tigray region for the period of 1980-2009. Detail investigations were carried out using parametric (Linear regression) and non-parametric tests (Mankendall and Sen's slope estimator). Moreover, homogeneity test was applied using a method developed by Van Belle and Hughes for the general trend analysis. Furthermore, the trend of rainfall end to characterize crop growth season using R-Instat and XLSTAT software. It was found that the general trend of monthly rainfall experienced an overall significant increasing trend. The seasonal rainfall experienced significantly increasing trend during the summer rainy season (June-September) whilst a significant decreasing trend occurred in the short rainy season (February-May). Likewise, the seasonal maximum temperature trends exhibited a significant increasing trend in all seasons whereas the minimum temperature showed inhomogeneous trend across seasons as well as stations. Despite significant increase of rainfall in summer season, the trend of growing season characteristics (onset, cessation, length of growing period and dry spell length) did not change significantly over the study period. However, the variability of rainfall and dry spell length was found to be very large. Hence, crop production in the study area demands appropriate adaptation strategies that considers the erratic nature of the rainfall, the long dry spell length in the season and increasing trends of temperature.
\end{abstract}




\section{Introduction}

Trends of temperature and precipitation, the most important parameters for crop production, have been changed over time in Ethiopia. For the past four decades, Ethiopia's annual average temperature has been increased by $0.37{ }^{0} \mathrm{C}$ per decade since 1951 (NMA 2007; Aragie 2013). Moreover, Ethiopia has experienced a high degree of interannual rainfall variability (Cheung et al 2008; Gebremicael et al. 2017; Mekasha et al. 2014; Meze-Hausken 2004; Seleshi and Zanke 2004). The changes in temperature and rainfall patterns as a result of climate variability and change are very critical to most of the population of the country who are dependent on rain-fed agriculture for their livelihoods. The impacts of increased temperature and changes in rainfall patterns are expected to reduce crop production and water availability for irrigation and other farming uses which is more pronounced in the north, northeast and eastern lowlands of the country (Aragie 2013).

Most of the droughts caused by climate variability and change have been occurred in the eastern and southern part of Tigray region (Gebrehiwot and van der Veen 2013). The climate of the study area is characterized by frequent droughts. Almost every year, localized droughts associated with variable and erratic rainfall has been the main reasons for crop productivity failures and hence jeopardizing livelihoods and development activities of the region (Awulachew et al. 2011; Gebrehiwot and Van der Veen 2013). Indeed, moisture stress stands to be the major limiting factor for crop and animal production in the eastern zone of the Tigray region (Meles et al. 1997). As a result, crop yield has been severely affected during part of its growing period (Araya and Stroosnijder 2010).

Although rainfall variability and associated localized droughts have been the greatest concern in the study area, few attempts have been made so far to quantify the spatio-temporal characteristics of precipitation and temperature. Yet, the emphasis of most of the studies related to the trend analysis so far carried out in Tigray region has been limited to rainfall analysis (Abraha 2015; Cheung et al 2008; Gebrehiwot et al 2011; Gebrehiwot and van der Veen 2013; Hayelom et al 2017; Gebremicael et al. 2017; Mekasha et al. 2014; Meze-Hausken 2004; Seleshi and Zanke 2004). Whereas temperature analysis has been ignored in many of these studies, although it is also vital for crop production and water-related issues.

In addition, the rainfall trend analyses made by many of the studies listed above are based on few station data and/or with few number of years especially regarding the study area (Eastern zone of Tigray) and many of the studies were restricted to even trends of annual or monthly or seasonal total values. Rainfall variability based on agricultural practices such as onset and cessation at an interval of days, length of growing period (LGP), and wet and dry spells weren't included in those studies with the only exception of Araya et al. (2010) who determined LGP of two crops, Teff (Eragrostis tef) and barley (Hordeum vulgare) in Giba catchment of the Tigray region. Yet, the rainfall and rainy season characteristics are important to make proper crop-based decisions in seeding, fertilizing, selecting crop variety, selecting suitable cropping pattern, and selecting the best agro-techniques. Assessing long-term trends of rainfall and rainy season characteristics (including onset, cessation and LGP) can help to formulate farming strategies to efficiently use the available water (Fiwa et al. 2014). Rainfall statistics for dry spells are also very important for the planning and management of water resources (Almazroui et al. 2017).

Overall, assessing spatio-temporal of changes in temperature \& rainfall, and rainfall characteristics was the main purpose of this research. Findings of this study will help to better understand the uncertainties associated with 
rainfall and temperature patterns and will favour knowledge-based management of agriculture, irrigation and other water related sectors in the region.

\section{Materials and methods}

\subsection{Description of the study area}

This study was carried out in the Eastern zone of Tigray region of Ethiopia, bordered on the east by the Afar Region, on the south-by-South Eastern zone of Tigray, on the west by central zone of Tigray and on the north by Eritrea. Its geographical location is between $13^{0} 33^{\prime} 2^{\prime \prime}-14^{0} 40^{\prime} 54^{\prime \prime}$ latitude and $39^{0} 11^{\prime} 39^{\prime \prime}-39^{0} 59^{\prime} 11^{\prime \prime}$ longitude (Figure 1). The zone has an area of 561,000 ha and seven districts (Erob, Hawzen, Wukro, Atsbi-Womberta, GantaAfeshum, Gulo-Mekeda and Saesie-TsaedaEmba). The altitude ranges between 1500-3280 meter above sea level (masl). The area is characterized by three traditional agro-ecologies of highland (>2300 masl), midland (1500-2300 masl) and lowland (<1500 masl) (Meles et al. 1997).

Three watersheds, namely Agulae, Suluh and Genfel were selected from the zone for this research purpose based on population growth, expansion of urbanization, and availability of small-scale irrigation schemes in each watershed (Figure 1). The livelihood of the community is mainly dependent on rainfed agriculture. Common rainfed crops in the watersheds include teff, wheat, barley, maize, sorghum and pulses. However, irrigation agriculture has increased significantly at household level in the recent years (Nyssen et al. 2010). According to Gebreyohannes et al. (2013), the dominant soil texture classes in the area is clay loam (40\%) followed by sandy clay loam (30\%), clay (19\%), loam (10\%), and sandy loam (1\%).

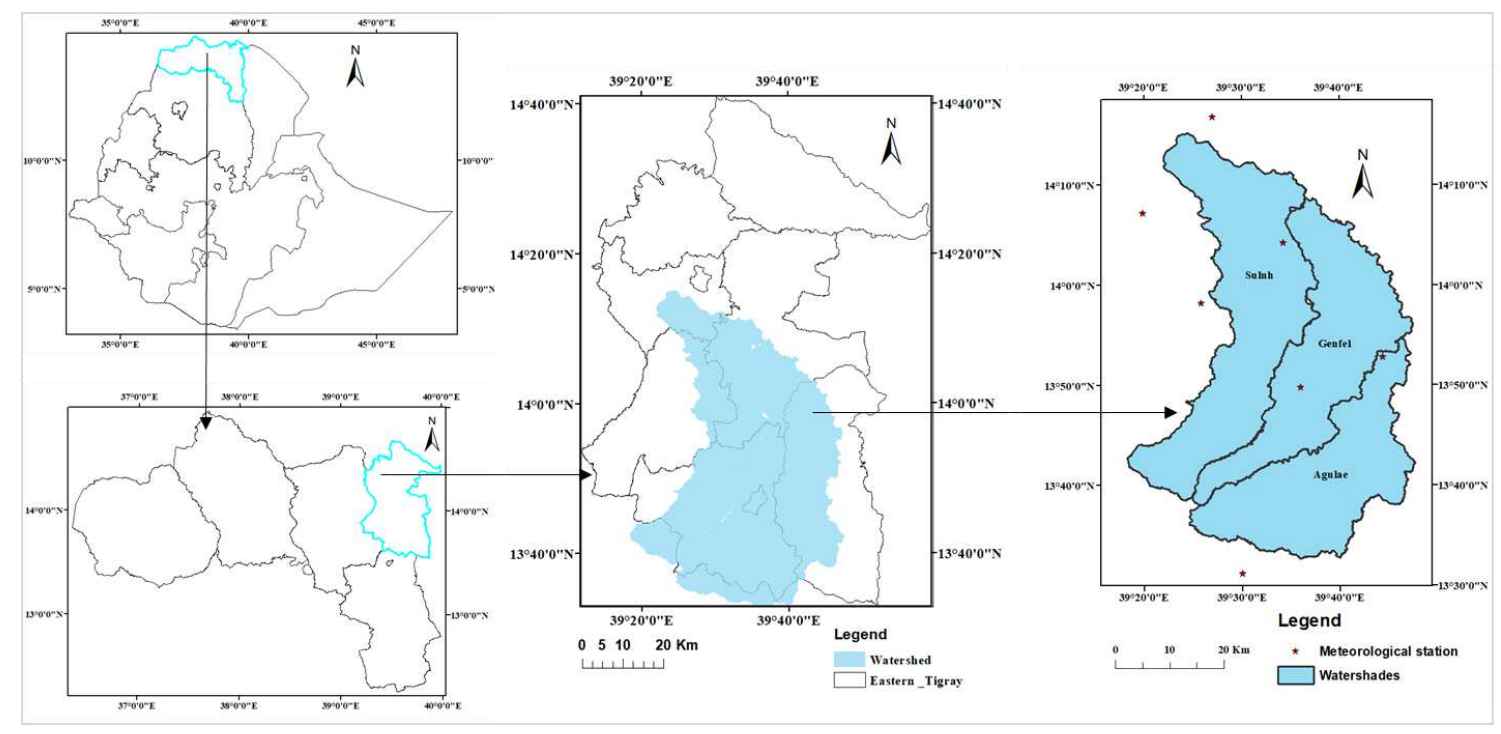

Figure 1: Location of the study area and selected watersheds

\subsection{Data used}

30 years of climate data (rainfall and temperatures) from seven stations within and nearby the Eastern zone of Tigray region from 1980-2009 were collected from Enhancing National Climate Services Initiative (ENACTS) recently implemented at Ethiopian National Meteorological Agency (NMA). The quality of provided climate data by ENACTS is improved by combining careful quality control of data from weather stations with that of satellite 
estimates. The combined data set is generated at a 10-daily time scale and for every $4 \mathrm{~km}$ grid across Ethiopia. This is the best available dataset for the country which is homogeneous and recommended for climate analysis (Dinku et al. 2014). The detailed information about ENACTS is elucidated in Dinku et al. (2014) and Dinku et al. (2018). The stations together along with their geographical locations and elevations are shown in (Table 1).

Table 1:Geographical location of the meteorological stations

\begin{tabular}{|l|c|c|c|}
\hline Station & Latitude (DD) & Longitude (DD) & Elevation (meter) \\
\hline Illala & 13.52 & 39.50 & 2012 \\
\hline Adigrat & 14.28 & 39.45 & 2470 \\
\hline Edagahamus & 14.12 & 39.33 & 2700 \\
\hline Atsbi & 13.88 & 39.74 & 2600 \\
\hline Sinkata & 14.07 & 39.57 & 2480 \\
\hline Wukro & 13.83 & 39.60 & 1995 \\
\hline Hawzen & 13.97 & 39.43 & 2255 \\
\hline
\end{tabular}

\subsection{Data analysis}

To identify linear and non-linear trends in monthly, annual and seasonal time scales of rainfall and temperature series, both parametric (linear regression) and non-parametric (Mann-Kendall and Sen's estimator of slope) statistical tests were considered. For homogeneity test of data the Van Belle and Hughes was also utilized.

\subsubsection{Linear regression}

A straight line is fitted to the data to determine whether the slope is different from zero or not. A simple linear regression method was used to determine the tendency (Eq. 1). Student t-test was applied to determine the statistically significance of the trend at a 5\% significant level.

$Y=a x+b$

Where: $\mathrm{Y}$ is the dependent variable, $\mathrm{a}$ is the slope, $\mathrm{x}$ is the independent variable and $\mathrm{b}$ is the intercept.

The parametric test is commonly applied to normal data. Hence, before analysis, the rainfall and temperature data were tested for normality using the Shapiro-Wilk test ( Shapiro and Wilk 1965). Shapiro-Wilk statistical test was widely used in several studies to test for normality of data (De Lima et al. 2010; Machiwal and Jha 2008; Muchuru et al. 2016; Suryadi and Sugianto 2018) and recommended for normality test as it provides better estimates, for example as compared to Kilmogorov-Smirnov method (Aura et al. 2019).

\subsubsection{Mann-Kendall and Theil-Sen's Slope estimator}

Monthly, seasonal and annual trends were assessed using the Mann-Kendall trend test (Kendall 1975) and Sen's slope estimator (Sen 1968) (2-5). The Mann-Kendall test and Sen's slope estimator are two non-parametric tests and widely applied in various trend detection studies (Asfaw et al. 2017; Chattopadhyay and Edwards 2016; Hamza et al. 2017; Palaniswami and Muthiah 2018; Samo et al. 2017).

\subsubsection{Mann-Kendall test}

The Mann-Kendall test S of the series X was calculated by applying equation 2 and 3 (Mann 1945; Kendall 1975): 


$$
\begin{aligned}
& S=\sum_{i=1}^{N-1} \sum_{j=i+1}^{N} \operatorname{sgn}\left(X_{j}-X_{i}\right) \\
& \operatorname{sgn}\left(X_{j}-X_{i}\right)=\left\{\begin{array}{c}
+1 \text { if }\left(X_{j}-X_{i}\right)>0 \\
0 \text { if }\left(X_{j}-X_{i}\right)=0 \\
-1 \text { if }\left(X_{j}-X_{i}\right)<0
\end{array}\right.
\end{aligned}
$$

Where, $\operatorname{sgn}\left(X_{j}-X_{i}\right)$ is the signum function, $X_{i}$ ranked from $i=1,2 \ldots N-1$ and $X_{j}$ ranked from $j=i+1,2 \ldots N$.

Each data point $X_{i}$ is used as a reference point and is compared with all other data points $X_{j}$ values.

The Mann-Kendal test statistics (S) represents asymptotically normal distribution and give the mean of zero and the variance of one (Mann 1945; Kendall 1975).

The variance associated with $S$ is calculated by applying equation 4:

$$
\operatorname{Var}(S)=\frac{1}{18}\left[N(N-1)(2 N+5)-\sum_{i=1}^{m} t_{i}\left(t_{i}-1\right)\left(2 t_{i}+5\right)\right]
$$

Where: $m$ is the number of tied groups and $t_{i}$ is the number of data points in group $i$

The standardized test statistic Z(S) is calculated by applying equation 5 (Mann 1945; Kendall 1975).

$$
Z(S)=\left\{\begin{array}{l}
\frac{S-1}{\sqrt{\operatorname{Var}(S)}} \text { if } S>0 \\
0 \quad \text { if } S=0 \\
\frac{S+1}{\sqrt{\operatorname{Var}(S)}} \text { if } S<0
\end{array}\right.
$$

The $H_{o}$ (null hypothesis) is rejected, if absolute value of $Z(S)$ is greater than $Z_{\text {critical }}\left(Z_{\alpha / 2}\right)$, in which $\alpha$ represents the level of significant. Positive values of normalized test statistics $Z(S)$ indicate an increasing trend and negative $Z$ values indicate decreasing trends. In this study, statistically significant level at 95\% confidence level (at $\alpha=0.05$ ) was used.

\subsubsection{Theil-Sen's Slope estimator}

This method is used to quantify the linear trend in time series analysis. The slope $\Theta i$ between two values in a time series $\mathrm{X}$ is estimated by equation 6 :

$$
\theta i=\frac{X_{k}-X_{j}}{k-j}, k \neq j, \quad \text { where } i=1,2, \ldots . N
$$

Where $X_{k}$ and $X_{j}$ are data values at times $k$ and $j(K>J)$

The median of these N values of $\Theta i$ is known as Sen's estimator of slope and calculated by equation 7. The positive sign of $\Theta_{\text {median }}$ represents an increasing trend while negative sign shows a decreasing trend. 


$$
\theta_{\text {median }}=\left\{\begin{array}{cc}
\theta_{\frac{(N+1)}{2}}, & N \text { odd } \\
\theta_{\frac{N}{2}}+\frac{\theta_{\frac{(N+1)}{2}}}{2}, & N \text { even }
\end{array}\right.
$$

\subsubsection{Van Belle and Huges' homogeneity of trend tests}

To test homogeneity of trends, the most widely used Van Belle and Hughes (Belle and Hughes 1984) test was applied. This provides a single statistic which indicates whether the months/seasons are behaving in similar (homogeneous) fashion or different (heterogeneous) from each other. This test uses Z-values (standardized test statistics $(\mathrm{Z}(\mathrm{S}))$ from MK-test statistics for each station.

To get the trend homogeneity of temperature and rainfall at multiple stations, Van Belle and Hughes proposed a procedure based on the partitioning of the sum of squares. The analysis procedure uses chi-square $\left(\mathrm{X}^{2}\right)$ test statistics of various chi-squares $\left(\mathrm{X}^{2}\right.$ homogeneous, $\mathrm{X}^{2}$ month/season, $\mathrm{X}^{2}$ station, $\mathrm{X}^{2}$ month/season-station interaction) for testing the trend homogeneity.

The formulas from 10-15 were used to test the homogeneity of the trends by partitioning the $\mathrm{X}_{\text {total }}^{2}$ into respective source of variations

1. $\mathrm{X}_{\text {total }}^{2}$

$$
X_{\text {total }}^{2}=\sum_{i=1}^{K} \sum_{m=1}^{M} Z_{i m}^{2}
$$

Where: $\mathrm{K}$ is the number of month or seasons, $\mathrm{M}$ is the number of stations and $\mathrm{Z}$ is the standardized test statistics with KM d.f.

2. Test for significant of common trend $\left(\mathrm{X}_{\text {trend }}^{2}\right)$

$$
X_{\text {trend }}^{2}=K M \bar{Z}^{2}
$$

Where: $\mathrm{K}$ is the number of month or seasons and $\mathrm{M}$ is the number of stations and, $\bar{Z}^{2}$ is the average square of standardized test statistics with 1 d.f.

3. Homogeneity trend test at different stations in different months/seasons ( $\mathrm{X}^{2}$ homogeneous $)$

$$
X_{\text {homogeneous }}^{2}=X_{\text {total }}^{2}-X_{\text {trend }}^{2}=\sum_{i=1}^{k}\left(Z_{i}\right)^{2}-k(\bar{Z})^{2}
$$

The values of $Z_{\mathrm{i}}$ and $\bar{Z}$ are calculated as:

$$
Z_{i}=\frac{S_{i}}{\sqrt{\operatorname{Var}\left(S_{i}\right)}} \text { and } \bar{Z}=\frac{1}{k} \sum_{i=1}^{k} Z_{i}
$$


Where: $\mathrm{S}_{\mathrm{i}}$ is the Mann-Kendall statistic for month $\mathrm{i}$, and $\mathrm{k}=12$ for monthly data values, with (KM-1) d.f.

4. Test for monthly or seasonal heterogeneity $\left(\mathrm{X}^{2}\right.$ month/season $)$

$$
X_{\text {month } / \text { season }}^{2}=M . \sum_{i=1}^{k}\left(\bar{Z}_{i M}\right)^{2}-X_{\text {trend }}^{2}
$$

Where: $\mathrm{M}$ is the number of stations with (K-1) d.f.

5. Test for station heterogeneity $\left(X^{2}\right.$ station $)$

$$
X_{\text {station }}^{2}=K \cdot \sum_{i=1}^{M}\left(\bar{Z}_{k M}\right)^{2}-X_{\text {trend }}^{2}
$$

Where: $\mathrm{K}$ is the number of month/season and with (M-1) d.f.

6. Test for the interaction $\left(\mathrm{X}^{2}\right.$ month/season-station $)$

$$
X_{\text {month } / \text { season-station }}^{2}=X_{\text {homogeneous }}^{2}-X_{\text {month or season }}^{2}-X_{\text {station }}^{2}
$$

During homogeneity test, four possible scenarios were examined based on Van Belle and Hughes (1984):

(i) When all values of $\mathrm{X}^{2}$ for stations, $\mathrm{X}^{2}$ months/ $\mathrm{X}^{2}$ seasons, and the interactions are non-significant

(ii) When values of $\mathrm{X}^{2}$ months $/ \mathrm{X}^{2}$ seasons is significant and $\mathrm{X}^{2}$ values of stations is non-significant, different trend direction of each months/seasons was tested using $\mathrm{M} \bar{Z}_{k}^{2},(\mathrm{i}=1,2, \ldots, \mathrm{K})$

(iii) When $\mathrm{X}^{2}$ values of stations is significant and $\mathrm{X}^{2}$ months $/ \mathrm{X}^{2}$ seasons is non-significant, different trend directions at each station was tested using $\mathrm{K} \bar{Z}_{m}^{2},(\mathrm{~m}=1,2, \ldots, \mathrm{M})$, and

(iv) When both months/seasons and stations or the interactions are significant, the only meaningful trend test was possible for individual month/season-station using $Z_{i m},(i=1,2, \ldots, K ; m=1,2, \ldots, M)$.

\subsubsection{Crop risk assessments}

In this study, crop risks associated with extreme events including dry spells and other growing season characteristics (e.g., Onset, Cessation and Length of Growing Period, LGP) was considered for the analysis in R-Instat (V.0.6.2) software (http://r-instat.org/Download) developed under the African Data Initiative (ADI) (https://africandata.org/). Growth season characteristics such as onset and cessation date, Length of Growing Period (LGP), and dry spell length were determined using 30 years of data from seven stations. Specific rainfall characteristics information is vital for crop planning and for carrying out agricultural operations. These are important to make crop-based decisions during seeding, fertilizing, selecting crop variety, selecting suitable cropping pattern, and selecting best agro techniques, etc.

Onset and cessation date: The onset of the rainy season in the Eastern zone of Tigray region was assumed to start as of June 19 after the wet spells occurred for at least three consecutive days and when the total rainfall is $20 \mathrm{~mm}$ or 
more if there was no dry spell longer than 7 or more days within 30 days. Moreover, the cessation date was assumed as the date when the stored soil moisture reaches $100 \mathrm{~mm}$ after rainfall falls below $\mathrm{ET}_{\mathrm{o}}$ values as per Higgins and Kassam (1981), which considers annual crops utilize 75-100 mm sored soil moisture during their harvest stage. The possible onset day was selected based on the information collected from farmers during the field survey. A minimum threshold value of rainfall $(<1 \mathrm{~mm})$ was considered as part of a dry spell, which is an insignificant amount for crop use (Siva Kumar 1992).

Length of Growing Period (LGP): The duration between the onset of the rain season (OS) and cessation of total seasonal rainfall (CS) represents the number of rainy days or the length of growing season (16).

$$
L G P=C S-O S
$$

Where: LGP is Length of Growing Season, CS is Cessation season rainfall and OS is onset season rainfall

Dry spell length is a time period with no rain or less than $0.1 \mathrm{~mm}$ rain for more than 7 days within 30 days. The average value of the dry spells was computed at a seasonal time scale during the main rainy season. 


\section{Results and Discussion}

\subsection{Annual and seasonal rainfall variability}

The mean rainfall amount throughout the study area was found to be $572 \mathrm{~mm}$ per annum. A minimum total rainfall amount of $554 \mathrm{~mm}$ was recorded in Edagahamus station while a maximum total amount of $617 \mathrm{~mm}$ was obtained in Hawzen station (Table 2). The contribution of "Kiremt"(local language) season to that of the annual total rainfall amount is very large in all stations which varies between $54 \%$ and $84 \%$. In addition, the contribution of the "Belg" season was not to be underestimated. In the majority of the stations, it contributed to more than $25 \%$ of the total rainfall. The "Belg" season is very useful for long-cycle crops. The long cycle crops are planted during this season before "Kiremt". Moreover, farmers also used this season for land management practices, such as repeated ploughing and in-situ soil moisture conservation activities.

However, the coefficient of variability (CV) of the total rainfall amount was much higher for "Belg "season that ranged from $37-45 \%$ than Kiremt season rainfall $(21-31 \%)$ and indicating a very higher temporal variability of the seasons (Table 2). Several studies also showed that the CV of "Belg" season is higher than "Kiremt" season in the northern Ethiopia (Hadgu et al. 2013; Kiros et al. 2017; Weldesenbet 2019). Of all stations, Hawzen showed the highest both 'Kiremt' and 'Belg' inter-annual variability with CV of $31 \%$ and $45 \%$, respectively). In general, the variability of the seasonal total rainfall in the study area can be categorized from moderate to high variability. Our finding agrees with previous studies that have reported the annual and seasonal rainfall variability showed moderate and high inter-annual variability (Ademe et al. 2020; Ayalew et al. 2012; Bewket and Conway 2007; Hadgu et al. 2013).

Table 2: Descriptive statistics of annual and seasonal (Kiremt and Belg) rainfall variables

\begin{tabular}{|c|c|c|c|c|}
\hline Stations & Variables & Annual & Kiremt & Belg \\
\hline \multirow[t]{3}{*}{ Ilalla } & Rainfall, mm & 569 & $392(69 \%)$ & $139(24 \%)$ \\
\hline & Std. deviation & 93 & 83 & 56 \\
\hline & $\mathrm{CV}(\%)$ & 16 & 21 & 41 \\
\hline \multirow[t]{3}{*}{ Edagahamus } & Rainfall, mm & 554 & $298(54 \%)$ & $195(35 \%)$ \\
\hline & Std. deviation & 89 & 67 & 75 \\
\hline & $\mathrm{CV}(\%)$ & 16 & 22 & 38 \\
\hline \multirow[t]{3}{*}{ Adigrat } & Rainfall, mm & 575 & $348(61 \%)$ & $179(31 \%)$ \\
\hline & Std. deviation & 105 & 96 & 73 \\
\hline & $\mathrm{CV}(\%)$ & 18 & 28 & 41 \\
\hline \multirow[t]{3}{*}{ Sinkata } & Rainfall, mm & 573 & $353(62 \%)$ & $167(29 \%)$ \\
\hline & Std. deviation & 80 & 75 & 62 \\
\hline & $\mathrm{CV}(\%)$ & 14 & 21 & 37 \\
\hline \multirow[t]{3}{*}{ Wukro } & Rainfall, mm & 556 & $387(70 \%)$ & $136(25 \%)$ \\
\hline & Std. deviation & 104 & 100 & 58 \\
\hline & $\mathrm{CV}(\%)$ & 19 & 26 & 42 \\
\hline \multirow[t]{3}{*}{ Atsbi } & Rainfall, mm & 560 & $375(67 \%)$ & $148(26 \%)$ \\
\hline & Std. deviation & 105 & 99 & 65 \\
\hline & $\mathrm{CV}(\%)$ & 19 & 26 & 44 \\
\hline \multirow[t]{3}{*}{ Hawzen } & Rainfall, mm & 617 & $519(84 \%)$ & $91(15 \%)$ \\
\hline & Std. deviation & 152 & 162 & 41 \\
\hline & $\mathrm{CV}(\%)$ & 25 & 31 & 45 \\
\hline
\end{tabular}




\subsection{Trend analysis of Rainfall and Temperature}

\subsubsection{Monthly rainfall trend}

The two-tailed MK and LR monthly rainfall statistical tests showed an increasing positive trend in all stations (Table 3). The magnitude of change is indicated by Sen's slope estimator that ranges from $0.29-0.99 \mathrm{~mm} / \mathrm{month}$ for June, $0.27-2.51 \mathrm{~mm} / \mathrm{month}$ for July, 0.82-2.96 mm/month for August and 0.22-0.55 mm/month for September. Nevertheless, June and July months showed statistically significant increasing trends in 3 of 7 stations and 4 of 7 stations at $p=0.1$, respectively. Each month showed statistically significant trend only in Hawzen station at $p=$ 0.05 level. Similarly, September showed a significant increasing trend only in Edagahamus station at $p=0.1$ level and other 2 of 7 stations (Sinkata and Wukro) at $p=0.05$ level. August month showed statistically non-significant increasing trends in all stations.

Table 3: Monthly rainfall (June-September) MK and LR statistical test values

\begin{tabular}{|c|c|c|c|c|c|c|c|c|}
\hline Rainfall & & & Stations & & & & \\
\hline \multirow{2}{*}{ Months } & Statistics & Illala & Edagahamus & Adigrat & \multirow{2}{*}{ Sinkata } & Wukro & \multirow{2}{*}{ Atsbi } & \multirow{2}{*}{ Hawzen } \\
\hline June & LR (t-test) & NN & NN & NN & NN & NN & NN & NN \\
\hline & MK (z-test) & $1.75^{* * *}$ & $1.71^{* * *}$ & 1.25 & 1.32 & 1.61 & $1.78^{* * *}$ & $2.00^{* *}$ \\
\hline & Sen's slope estimate & 0.52 & 0.38 & 0.30 & 0.29 & 0.34 & 0.31 & 0.99 \\
\hline & Sen's slope (95\% CI) & $0.4-0.7$ & $0.3-0.5$ & $0.2-0.4$ & $0.2-0.4$ & $0.2-0.4$ & $0.3-0.4$ & $0.8-1.1$ \\
\hline July & LR (t-test) & NN & NN & NN & NN & NN & NN & NN \\
\hline & MK (z-test) & $1.82^{* * *}$ & 0.39 & $1.82^{* * *}$ & $1.68 * * *$ & $1.64 * * *$ & 1.03 & $2.07 * *$ \\
\hline & Sen's slope estimate & 1.16 & 0.27 & 1.30 & 1.29 & 1.55 & 1.07 & 2.51 \\
\hline & Sen's slope (95\% CI) & $1.0-1.6$ & $0.03-0.6$ & $1.1-1.5$ & $1.0-1.7$ & $1.3-1.8$ & $0.8-1.6$ & $2.1-2.8$ \\
\hline August & LR (t-test) & 0.76 & 1.21 & 1.72 & 1.01 & 1.62 & 1.87 & 1.29 \\
\hline & MK (z-test) & 0.54 & 1.03 & 1.36 & 0.89 & 1.43 & 1.57 & 1.53 \\
\hline & Sen's slope estimate & 0.82 & 1.17 & 2.04 & 1.00 & 2.26 & 2.27 & 2.96 \\
\hline & Sen's slope (95\% CI) & $0.5-1.3$ & $0.8-1.7$ & $1.4-2.5$ & $0.5-1.7$ & $1.7-2.8$ & $1.8-2.8$ & $2.2-3.5$ \\
\hline September & LR (t-test) & 0.89 & $1.95 * * *$ & 1.40 & $2.10^{* *}$ & $2.20^{* *}$ & 1.52 & 0.44 \\
\hline & MK (z-test) & 0.89 & $1.82^{* * *}$ & 1.14 & $1.96 * *$ & $2.07 * *$ & 1.53 & 0.71 \\
\hline & Sen's slope estimate & 0.22 & 0.22 & 0.26 & 0.31 & 0.55 & 0.52 & 0.27 \\
\hline & Sen's slope (95\% CI) & $0.1-0.3$ & $0.2-0.3$ & $0.2-0.4$ & $0.3-0.34$ & $0.4-0.6$ & $0.4-0.6$ & $0.2-0.5$ \\
\hline
\end{tabular}

NN-Non-normal data $* *$ Statistically significant at 5\% significance level, $* * *$ Statistically significant at $10 \%$ significance level

\subsubsection{Seasonal rainfall, maximum and minimum temperature trends}

Table 4 and 5 showed seasonal trends of rainfall, maximum and minimum temperatures. The values obtained from the LR-test statistics are higher than those values obtained from the MK-test in most of the stations for all variables. Nevertheless, the significance trend direction results obtained from the LR test are in line with those obtained from the MK test in all incidences.

Annual rainfall showed a positive increasing trend in most of the stations and varied from $0.8-5.51 \mathrm{~mm} /$ year (Table

4). In addition, "Kiremt" season rainfall values also showed an increasing positive trend varied from 2.34-6.78 $\mathrm{mm} /$ season whilst "Belg" season showed a decreasing trend varied from 0.74-2.29 mm/season (Table 4). However, 
annual and seasonal trends are found to be non-significant at 5\% significant level. Our results corroborate the findings of previous studies that indicated non-significant rainfall trend in northern Ethiopia (Cheung et al 2008; Gebremicael 2017; Gebremicael 2020; Seleshi and Camberlin 2006; Seleshi and Zanke 2004; Viste et al 2012).

Compared to all stations, Hawzen station showed the highest increasing trend magnitude of annual (5.51 mm/year) and Kiremt $(6.78 \mathrm{~mm} / \mathrm{season})$ rainfall. In contrast, Edagahamus station showed the highest decreasing trend magnitude during the Belg rainfall season (2.29 mm/season). Few stations (Adigrat, Sinkata and Wukro) showed a significant increasing Kiremt rainfall and significant decreasing Belg rainfall (Edagahamus) at $p=0.1$ level.

Table 4: Seasonal rainfall statistical trend values

\begin{tabular}{|c|c|c|c|c|c|c|c|c|}
\hline & & & Stations & & & & & \\
\hline $\begin{array}{c}\text { Rainfall } \\
(\mathbf{m m})\end{array}$ & Statistics & Illala & Edagahamus & Adigrat & Sinkata & Wukro & Atsbi & Hawzen \\
\hline \multirow{4}{*}{ Annual } & LR (t-test) & 0.47 & -0.11 & 0.93 & 0.73 & 1.40 & 1.42 & 1.25 \\
\hline & MK (z-test) & 0.32 & -0.25 & 0.86 & 0.64 & 1.43 & 1.50 & 1.43 \\
\hline & Sen slope estimate & 0.8 & -0.82 & 2.12 & 1.3 & 3.12 & 3.24 & 5.51 \\
\hline & $\begin{array}{c}\text { Sen's slope }(95 \% \\
\text { CI) }\end{array}$ & $-0.1-1.7$ & $-1.4-0.4$ & $1.3-3.2$ & $0.6-1.8$ & $2.2-3.9$ & $2.4-3.6$ & $3.9-6.7$ \\
\hline \multirow{4}{*}{ Kiremt } & LR (t-test) & 1.28 & 1.36 & 1.75 & $1.69 * * *$ & $1.85^{* * *}$ & $1.86^{* * *}$ & 1.46 \\
\hline & MK (z-test) & 1.14 & 1.61 & 1.53 & $1.78 * * *$ & $1.64 * * *$ & $1.78^{* * *}$ & 1.61 \\
\hline & Sen slope estimate & 2.34 & 2.38 & 3.19 & 2.93 & 3.97 & 3.61 & 6.78 \\
\hline & $\begin{array}{l}\text { Sen's slope }(95 \% \\
\text { CI) }\end{array}$ & $1.6-2.9$ & $1.8-2.7$ & $2.8-4.2$ & $2.5-3.2$ & $2.9-5.1$ & $3.2-4.3$ & $6.0-7.6$ \\
\hline \multirow{4}{*}{ Belg } & LR (t-test) & -1.13 & $\mathrm{NN}$ & $\mathrm{NN}$ & $\mathrm{NN}$ & NN & $\mathrm{NN}$ & $\mathrm{NN}$ \\
\hline & MK (z-test) & -1.07 & $-1.89 * * *$ & -1.57 & -1.32 & -1.03 & -1.18 & -1.07 \\
\hline & Sen slope estimate & -1.27 & -2.29 & -1.94 & -1.67 & -0.84 & -1.05 & -0.74 \\
\hline & $\begin{array}{c}\text { Sen's slope }(95 \% \\
\text { CI) }\end{array}$ & $-1.7-(-1)$ & $-2.8-(-2.1)$ & $-2.4-(-1.5)$ & $-1.9-(-1.2)$ & $-1.2-(-0.4)$ & $-1.4-(-0.7)$ & $\begin{array}{c}-1.1-(- \\
0.4) \\
\end{array}$ \\
\hline
\end{tabular}

NN-Non-normal data, $* *$ Statistically significant at 5\% significance level, *** Statistically significant at $10 \%$ significance level

The seasonal temperature exhibited non-uniform trend directions across the stations (Table 5). A significant increasing trend of maximum and minimum temperature, with a magnitude of $\left(0.04-0.07^{\circ} \mathrm{C} /\right.$ year, $0.024-$ $0.06^{\circ} \mathrm{C} /$ year $)$ and $\left(0.07-0.1^{\circ} \mathrm{C} /\right.$ season, $0.06-0.12^{\circ} \mathrm{C} /$ season, respectively) were observed during annual and Belg season in all stations at $p=0.01$ significance level. Unlike the annual and "Belg" season, the maximum and minimum Kiremt season temperature showed an increasing and decreasing trend patterns. In most of the stations (5 out of 7), such as Illala, Edagahamus, Adigrat, Sinkata and Hawzen, the maximum temperature showed an increasing trend whereas in Wukro and Atsbi stations it showed a decreasing trend. In the case of minimum Kiremt temperature, a decreasing trend was observed in most of the stations (6 out of 7) except in Edagahamus. Yet, the Kiremt season maximum and minimum temperatures trends were not statistically significant at a $5 \%$ significant level in most of the stations. Few stations such as Edagahamus and Hawzen showed a significant increasing maximum temperature with a magnitude of $0.08^{\circ} \mathrm{C} /$ season, at $p=0.01$ level and $0.02^{\circ} \mathrm{C} /$ season, at $p=0.1$ level, 
respectively. Moreover, Adigrat and Hawzen stations showed a significant decreasing trend in minimum temperature by $0.04^{\circ} \mathrm{C} /$ season at $p=0.01$ level and $0.03^{\circ} \mathrm{C} /$ season at $p=0.1$ level, respectively.

Table 5:Seasonal maximum and minimum temperature statistical trend values

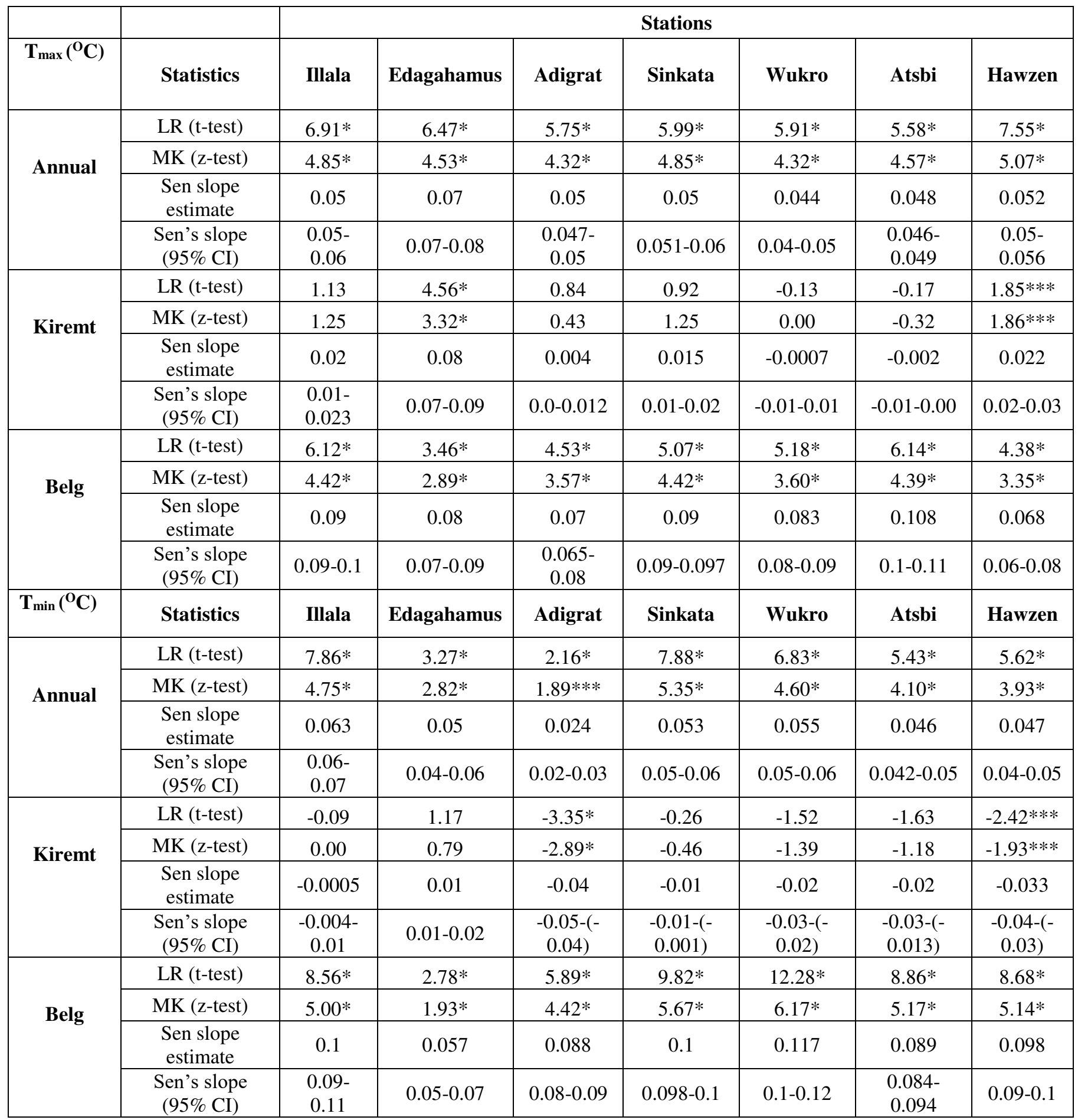

NN-Non-Normal data, *Statistically significant at $1 \%$ significance level, ** Statistically significant at $5 \%$ significance level, $* * *$ Statistically significant at $10 \%$ significance level

\subsection{Test of homogeneity of trends}




\subsubsection{Monthly and seasonal rainfall homogeneity}

In the monthly rainfall series (June-September), none of the station, season and station-season interaction components exhibited significant trend heterogeneity since $\mathrm{X}^{2}$ station, $\mathrm{X}^{2}$ month, and the interaction are less than the $\mathrm{X}^{2}$ critical values (Table 6). But, the overall trend heterogeneity was found to be significant since $\mathrm{X}^{2}$ trend $>\mathrm{X}^{2}$ critical. The average of Mann-Kendall test statistics over months $(\mathrm{k}=1,2,3,4)$ and stations $(\mathrm{m}=1,2, \ldots .7)$ was found to be positive $(\bar{Z}=1.44)$ indicating an increasing trend.

However, in annual and seasonal (Belg and Kiremt) rainfall series, $\mathrm{X}^{2}$ season only exhibited seasonal heterogeneity of rainfall trend since $\mathrm{X}^{2}$ season is greater than $\mathrm{X}^{2}$ critical values. However, the stations were found to have homogeneous trends (Table 7). Hence, according to scenario (ii) trend direction analysis at each season using $\mathrm{K}$ seasonal statistics becomes necessary while each season refers to the value of $X^{2}$ critical (with d.f.=1, i.e., 6.64) at $1 \%$ significant level. In evaluating the various homogeneity test it is best to use high significance level to obtain the same $\mathrm{Z}$ statistical sign by neglect small differences in the trend magnitude not seem too important (Belle and Huges, 1984).

Significance of trend homogeneity for each season was tested using the average Mann-Kendal test statistics $\left(Z_{k}\right)$. The $M \bar{Z}_{k}^{2}$ was obtained to test the overall seasonal trend homogeneity. Accordingly, the K seasonal statistics of $M \bar{Z}_{k}^{2}$ becomes less than the $\mathrm{X}^{2}$ critical values for annual and greater for Kiremt and Belg seasons (Table 8). As a result, despite previous studies do not show any clear signs of changing rainfall pattern in north Ethiopia (Viste et al 2012; Seleshi and Zanke 2004; Seleshi and Camberlin 2006; Cheung et al 2008), the Van Belle and Huges for general trend test indicated that the annual rainfall did not increase significantly while Kiremt increased significantly and Belg rainfall decreased significantly in Easter zone of Tigray region in Northern Ethiopia.

Table 6: Significance test of trend homogeneity for monthly rainfall (June-September)

\begin{tabular}{|c|c|c|c|c|c|}
\hline Source & $\mathrm{X}^{2}$ value & d.f. & $\begin{array}{c}\mathrm{X}^{2} \text { critical, at } \\
5 \%\end{array}$ & $\begin{array}{c}\mathrm{X}^{2} \text { critical, } \\
\text { at } 1 \%\end{array}$ & Sign. \\
\hline Total & 63.67 & $\mathrm{~K} . \mathrm{M}=4 * 7=28$ & 41.34 & 48.28 & - \\
\hline Homogeneous & 5.71 & $\mathrm{~K} . \mathrm{M}-1=28-1=27$ & 40.11 & 46.96 & - \\
\hline Month & 0.70 & $\mathrm{~K}-1=4-1=3$ & 7.82 & 11.35 & \\
\hline Station & 0.64 & $\mathrm{M}-1=7-1=6$ & 12.59 & 16.8 & \\
\hline Month-Station & 4.36 & $(\mathrm{~K}-1)^{*}(\mathrm{M}-1)=18$ & 28.87 & 34.81 & \\
\hline Monthly homogeneity & & $\mathrm{X}^{2}$ months $<\mathrm{X}^{2}$ critical & & & $\mathrm{NS}$ \\
\hline Station homogeneity & & $\mathrm{X}^{2}$ station $<\mathrm{X}^{2}$ critical & & & $\mathrm{NS}$ \\
\hline Interaction & & $\mathrm{X}^{2}$ months-station $<\mathrm{X}^{2}$ critical & & & $\mathrm{NS}$ \\
\hline Trend & 57.96 & $1=1$ & 3.8 & 6.64 & $\mathrm{~S}$ \\
\hline Global trend & & $\mathrm{X}^{2}$ trend $>\mathrm{X}^{2}$ critical & & & Trend \\
\hline
\end{tabular}

Sign.: Significance; NS: not significant; S: significant; d.f.: degrees of freedom 
Table 7: Significance test of trend homogeneity for seasonal rainfall (Annual, Kiremt, Belg)

\begin{tabular}{|c|c|c|c|c|c|}
\hline Source & $\begin{array}{c}\mathrm{X}^{2} \\
\text { value }\end{array}$ & d.f. & $\begin{array}{c}\mathrm{X}^{2} \text { critical, at } \\
5 \%\end{array}$ & $\begin{array}{c}\mathrm{X}^{2} \text { critical, } \\
\text { at } 1 \%\end{array}$ & Sig. \\
\hline Total & 38.04 & 21 & 32.67 & 38.93 & - \\
\hline Homogeneous & 35.08 & 20 & 31.41 & 37.57 & - \\
\hline Season & 31.56 & 2 & 5.99 & 9.21 & \\
\hline Station & 1.96 & 6 & 12.59 & 16.81 & \\
\hline Season-Station & 1.56 & 12 & 21.03 & 26.22 & \\
\hline Seasonal homogeneity & & $\mathrm{X}^{2}$ seasons $>\mathrm{X}^{2}$ critical & & & $\mathrm{S}$ \\
\hline Station homogeneity & & $\mathrm{X}^{2}$ station $<\mathrm{X}^{2}$ critical & & & NS \\
\hline Interaction & & $\mathrm{X}^{2}$ seasons-station $<\mathrm{X}^{2}$ critical & & & NS \\
\hline $\mathrm{X}^{2}$ trend & 2.96 & 1 & 3.8 & 6.64 & Not used \\
\hline
\end{tabular}

Sign.: Significance; NS: not significant; S: significant; d.f.: degrees of freedom

Table 8: Seasonal rainfall trend test result for the stations

\begin{tabular}{|l|r|r|r|c|}
\hline \multicolumn{1}{|c|}{ Season } & $\bar{Z}_{K}$ & $\bar{Z}_{k}^{2}$ & \multicolumn{1}{l|}{$\mathrm{M}_{k}^{2}$} & Significance \\
\hline Annual & 0.85 & 0.72 & 5.01 & $\mathrm{NS}$ \\
\hline Kiremt & 1.59 & 2.51 & 17.59 & $\mathrm{~S}$ \\
\hline Belg & -1.30 & 1.70 & 11.92 & $\mathrm{~S}$ \\
\hline
\end{tabular}

\subsubsection{Maximum and Minimum temperature homogeneity}

The value of $\mathrm{X}^{2}$ season for maximum and minimum temperature was significant which suggests heterogeneous (Table 9), In contrast, the value of $\mathrm{X}^{2}$ station for maximum and minimum temperature was non-significant indicating homogeneous time series data. According to scenario (ii), testing trend direction at each season using $\mathrm{K}$ seasonal statistics becomes necessary.

Table 10 and 11 indicated that the computed $M \bar{Z}_{k}^{2}$ values for seasons were found to be greater than the critical $\mathrm{X}^{2}$ (equal to 6.64) with d.f. $=1$ at $1 \%$ significance level. Hence, the annual, Belg and Kiremt maximum temperature increased significantly (Table 10). Similarly, annual and Belg minimum temperature increased significantly while Kiremt decreased significantly (Table 11).

The trends in minimum temperature of the different seasons were not homogeneous in the study area as the trends in Kiremt were different from that of annual and Belg seasons. It is also noticeable 6 out of the 7 stations had negative trends in the season of Kiremt, while all stations experienced positive trends in annual and Belg season. 
Table 9: Maximum and Minimum temperature homogeneity test statistics

\begin{tabular}{|c|c|c|c|c|c|c|c|c|c|c|}
\hline \multirow[t]{2}{*}{ Sources } & \multicolumn{5}{|c|}{ Maximum Temperature } & \multicolumn{5}{|c|}{ Minimum Temperature } \\
\hline & $\begin{array}{c}\mathrm{X}^{2}- \\
\text { value }\end{array}$ & d.f. & $\begin{array}{c}\mathrm{X}^{2} \\
\text { critical, } \\
\text { at } 5 \%\end{array}$ & $\begin{array}{c}\mathrm{X}^{2} \\
\text { critical, } \\
\text { at } 1 \%\end{array}$ & Sign. & $\begin{array}{c}\mathrm{X}^{2}- \\
\text { value }\end{array}$ & d.f. & $\begin{array}{c}\mathrm{X}^{2} \\
\text { critical, } \\
\text { at } 5 \%\end{array}$ & $\begin{array}{c}\mathrm{X}^{2} \\
\text { critical, } \\
\text { at } 1 \%\end{array}$ & Sign. \\
\hline Total & 273.05 & 21 & 32.67 & 38.93 & - & 304.05 & 21 & 32.67 & 38.93 & - \\
\hline Homogeneous & 59.67 & 20 & 35.17 & 37.57 & - & 165.81 & 20 & 35.17 & 37.57 & - \\
\hline Seasons & 47.71 & 2 & 5.99 & 9.21 & $\mathrm{~S}$ & 136.83 & 2 & 5.99 & 9.21 & $\mathrm{~S}$ \\
\hline Station & 2.96 & 6 & 12.59 & 16.81 & NS & 12.88 & 6 & 12.59 & 16.81 & $\mathrm{NS}^{@ 1 \%}$ \\
\hline Season-Station & 9.00 & 12 & 21.03 & 26.22 & $\mathrm{NS}$ & 16.10 & 12 & 21.03 & 26.22 & NS \\
\hline Trend & 213.38 & 1 & 3.84 & 6.64 & Not used & 138.24 & 1 & 3.84 & 6.64 & Not used \\
\hline
\end{tabular}

Sign.: Significance; NS: not significant; S: significant; d.f.: degrees of freedom

Table 10: Seasonal maximum temperature homogeneity test statistics

\begin{tabular}{|l|r|r|r|l|}
\hline & \multicolumn{1}{|c|}{$\bar{Z}_{K}$} & \multicolumn{1}{|c|}{$\bar{Z}_{k}^{2}$} & $\mathrm{M}_{k}^{2}$ & Sign. \\
\hline Annual & 4.64 & 21.56 & 150.95 & $\mathrm{~S}$ \\
\hline Kiremt & 1.11 & 1.23 & 8.64 & $\mathrm{~S}$ \\
\hline Belg & 3.81 & 14.50 & 101.49 & $\mathrm{~S}$ \\
\hline
\end{tabular}

Table 11: Seasonal minimum temperature homogeneity test statistics

\begin{tabular}{|l|r|r|r|l|}
\hline & $\bar{Z}_{K}$ & \multicolumn{1}{|c|}{$\bar{Z}_{k}^{2}$} & $\mathrm{M}_{k}^{2}$ & Sign. \\
\hline Annual & 3.92 & 15.37 & 107.56 & $\mathrm{~S}$ \\
\hline Kiremt & -1.01 & 1.02 & 7.13 & $\mathrm{~S}$ \\
\hline Belg & 4.79 & 22.91 & 160.37 & $\mathrm{~S}$ \\
\hline
\end{tabular}

\subsection{Trend characteristics of crop growing season}

Table 12 presents the computed statistics on the crop growth season characteristics (Mann Kendall's-tau, and Sen's slope estimator) at a 5\% significant level values. The 30-years median early onset date of the Kiremt season was found to be within the range of 30-June/ 182.5 DOY (Day of Year) at Hawzen to 8-July/190 DOY at Wukro. The onset dates of Ilalla, Adigrat, Edagahamus, Wukro and Atsbi are very close to Hawzen station. The onset date variability was lower $(\mathrm{CV}<10 \%)$ at all stations.

The median cessation date indicated a wide range of dates among the stations. The earliest cessation was on 11Sep./255 DOY at Edagahamus and late cessation was on 25-Sep/269 DOY at Hawzen. As compared to the onset date, cessation variability was very low $(<5 \%)$ at all stations. The $\mathrm{CV}$ of onset and cessation periods is small $(<10 \%)$ which may relatively a stable onset and cessation. Stable onset and cessation is advantageous for the farmers in searching other off farm activities once they have stabilized onset and cessation dates.

Table 12 also showed the time series of LGP for the different stations. There is a general increasing trend of LGP which could be attributed to the observed early in onset and delay in the cessation date. Median LGP values in the study area varied from 68 days at Edagahamus to 85 days at Hawzen. Previous studies applied different criterions 
for onset and cessation analysis and reported LGP in the north eastern stations ranged from 60-100 days (Berhe 2011; Gebre et al. 2013). The CV in LGP was larger than 15\% in all stations, suggesting crop growing season are relatively unstable and relaying on one type of crop is risky in the study area. However, providing such kind of information is essential in selecting crop cultivars that can grow based on their maturity.

Similarly, the mean seasonal dry spell length was analysed and found to be in the range of 24 days at Adigrat to 30 days at Edagahamus. The dry spell length was highly variable with CV of 25 to $43 \%$. This indicates availability of high risk on intra-seasonal water deficit in the study area. These findings agree with those of Gebreselassie and Moges (2016) who reported greater than $30 \%$ of variability in the dry spell length of daily rainfall. The highest variability of dry spell length was observed at Illala while the lowest was occurred at Edagahamus station.

Table 12: Statistical values and trends of onset, cessation, LGP and dry spell length

\begin{tabular}{|c|c|c|c|c|c|c|c|c|}
\hline \multirow[t]{2}{*}{$\begin{array}{l}\text { Characteristics } \\
\text { of crop growth }\end{array}$} & \multirow[t]{2}{*}{ Statistics } & \multicolumn{7}{|c|}{ Stations } \\
\hline & & Illala & Adigrat & Edagahamus & Wukro & Hawzen & Sinkata & Atsbi \\
\hline \multirow[t]{6}{*}{ Onset } & Median & 7-Jul & 7-Jul & 6-Jul & 8-Jul & 30-Jun & 4-Jul & 7-Jul \\
\hline & Kendall's tau & -0.07 & -0.10 & -0.16 & -0.06 & -0.01 & -0.18 & 0.07 \\
\hline & Slope & -0.10 & -0.13 & -0.29 & -0.07 & -0.05 & -0.27 & 0.06 \\
\hline & $\mathrm{P}_{\text {Value }}$ & 0.60 & 0.45 & 0.23 & 0.68 & 0.94 & 0.17 & 0.60 \\
\hline & SD (Days) & 9 & 9 & 11 & 8 & 13 & 12 & 7 \\
\hline & $\mathrm{CV} \%$ & 5 & 5 & 6 & 4 & 7 & 6 & 4 \\
\hline \multirow[t]{6}{*}{ Cessation } & Median & 22-Sep & 20-Sep & 11-Sep & 21-Sep & 25-Sep & 20-Sep & 23-Sep \\
\hline & Kendall's tau & 0.16 & 0.24 & 0.03 & 0.18 & 0.15 & 0.19 & 0.20 \\
\hline & Slope & 0.14 & 0.13 & 0.00 & 0.20 & 0.15 & 0.13 & 0.30 \\
\hline & $P_{\text {Value }}$ & 0.23 & 0.09 & 0.85 & 0.17 & 0.25 & 0.15 & 0.13 \\
\hline & SD (Days) & 6 & 7 & 3 & 7 & 7 & 6 & 9 \\
\hline & $\mathrm{CV} \%$ & 2 & 3 & 1 & 3 & 3 & 2 & 3 \\
\hline \multirow[t]{6}{*}{ LGP } & Median & 74 & 72 & 68 & 74 & 85 & 77 & 78 \\
\hline & Kendall's tau & 0.10 & 0.16 & 0.14 & 0.16 & 0.06 & 0.19 & 0.11 \\
\hline & Slope & 0.25 & 0.35 & 0.29 & 0.33 & 0.20 & 0.50 & 0.25 \\
\hline & $P_{\text {Value }}$ & 0.44 & 0.24 & 0.30 & 0.22 & 0.68 & 0.15 & 0.40 \\
\hline & SD (Days) & 11 & 11 & 12 & 11 & 14 & 13 & 11 \\
\hline & $\mathrm{CV} \%$ & 15 & 16 & 17 & 15 & 16 & 17 & 15 \\
\hline \multirow[t]{6}{*}{ Dry Spell } & Mean & 26 & 24 & 30 & 23 & 26 & 27 & 29 \\
\hline & Kendall's tau & -0.10 & -0.12 & -0.25 & -0.12 & -0.06 & -0.07 & 0.06 \\
\hline & Slope & -0.18 & -0.11 & -0.23 & -0.16 & -0.10 & -0.08 & 0.08 \\
\hline & $\mathrm{P}_{\text {Value }}$ & 0.47 & 0.35 & 0.06 & 0.38 & 0.65 & 0.59 & 0.67 \\
\hline & SD (Days) & 11 & 8 & 7 & 9 & 10 & 10 & 10 \\
\hline & CV (\%) & 43 & 34 & 25 & 39 & 37 & 36 & 34 \\
\hline
\end{tabular}

\section{Conclusions}

This study analyzed the variability and trends of rainfall, temperature and characteristics of crop growth seasons in Eastern zone of Tigray region. Despite the observed significant trends in the rainfall and temperature in the study 
area, the trend of growing season characteristics did not change significantly in all stations over the study period. In addition, the coefficient of variability of the onset $(\mathrm{CV},<10 \%)$ and Cessation $(\mathrm{CV},<5 \%)$ indicated very small, possibly relatively stable onset and cessation. However, the coefficient of variability of LGP was (CV, >15\%) indicates unstable and how risky was crop production under rain-fed condition relying in one type of crop in the study area. Moreover, the CV of the dry spell length was (CV, >25\%) this also showed the high risk of intraseasonal water deficit situation in the study area. Overall, the higher variability of rainfall amount of Kiremt and Belg seasons and the higher variability of dry spell length of (CV, >25\%) in association with short nature of LGP (68-85 days) had a negative impact on the agricultural activities of the study area during the study period (19802009). Hence, crop production in the study area demands appropriate adaptation strategies that considers the erratic nature of the rainfall, the long dry spell length in the season and increasing trend of temperature.

Acknowledgments The authors are thankful to the African Climate Change Adaptation Initiative (ACCAI-II B) project and to the Institute of climate and Society at Mekelle University for the financial support. We would also like to acknowledge to the National Meteorological Agency of Ethiopia for providing the weather data.

Availability of data and material The weather data used in the study were obtained from Ethiopian National Meteorological Agency (NMA). Access to the data can be obtained from NMA based on justifiable request.

Code availability Not applicable

Authors' contributions All the authors made a valuable contribution to this study. AGB has designed the study, collected and analyzed data, interpreted the results, and wrote the draft manuscript. SHM, GGA and AZA have participated in designing the study, analysis and interpretation, structuring the manuscript; and provided critical comments and suggestions on the draft manuscript. All authors read and approved the final manuscript.

Funding The authors are thankful to the African Climate Change Adaptation Initiative (ACCAI-II B) project and to the Institute of climate and Society at Mekelle University for the financial support to undertake this study.

\section{Declarations}

Ethics approval and consent to participate

Not applicable.

\section{Consent for publication}

Not applicable.

Conflict of interests

No potential conflict of interest was reported by the authors. 


\section{References}

Abrha, MG (2015) Local climate trends and farmers' perceptions in southern Tigray, Northern Ethiopia. International Journal of Environment and Sustainability, 4(3)

Almazroui M, Balkhair KS, Islam MN, Şen Z (2017) Climate Change Impact on Monthly Precipitation Wet and Dry Spells in Arid Regions: Case Study over Wadi Al-Lith Basin. Advances in Meteorology, 2017

Aragie EA (2013) Climate change, growth, and poverty in Ethiopia, Texas Univ at Austin

Araya A, Stroosnijder L (2010) Effects of tied ridges and mulch on barley (Hordeum vulgare) rainwater use efficiency and production in Northern Ethiopia. Agricultural water management, 97(6):841-847

Araya A, Keesstra SD, Stroosnijder L (2010) A new agro-climatic classification for crop suitability zoning in northern semi-arid Ethiopia. Agricultural and forest meteorology, 150(7-8):1057-1064

Asfaw A, Simane B, Hassen A, Bantider A (2017) Variability and time series trend analysis of rainfall and temperature in northcentral Ethiopia: A case study in Woleka sub-basin. Weather and Climate Extremes

Aura S, Muita R, Oloo P, Muchemi D, Kucera P, Mwangi S, Steinson M (2019) Intercomparison of tahmo, 3dpaws automatic weather stations and kmd's dagoretti corner, nairobi synoptic weather station data

Ayalew D, Tesfaye K, Mamo G, Yitaferu B, Bayu W (2012) Variability of rainfall and its current trend in Amhara region. Ethiopia Afr J Agric Res 7(10):475-1486

Belle G, Hughes JP (1984) Nonparametric tests for trend in water quality. Water resources research, 20(1):127-136

Berhe AA (2011) Coping with drought for food security in Tigray, Ethiopia

Bewket W, Conway D (2007) A note on the temporal and spatial variability of rainfall in the drought-prone Amhara region of Ethiopia. Int J Climatology 27(11):1467-1477

Chattopadhyay S, Edwards DR (2016) Long-term trend analysis of precipitation and air temperature for Kentucky, United States. Climate, 4(1): 10

Cheung WH, Senay GB, Singh A (2008) Trends and spatial distribution of annual and seasonal rainfall in Ethiopia. International Journal of Climatology: A Journal of the Royal Meteorological Society, 28(13):1723-1734

Conway D (2000) The climate and hydrology of the Upper Blue Nile River. Geographical Journal, 166(1): 49-62

De Lima MIP, Carvalho SCP, De Lima JLMP (2010) Investigating annual and monthly trends in precipitation structure: an overview across Portugal. Natural Hazards and Earth System Sciences, 10(11): 2429

Dinku T, Hailemariam K, Maidment R, Tarnavsky E, Connor S (2014) Combined use of satellite estimates and rain gauge observations to generate high-quality historical rainfall time series over Ethiopia. International Journal of Climatology, 34(7): 2489-2504

Dinku T, Funk C, Peterson P, Maidment R, Tadesse T, Gadain H, Ceccato P (2018) Validation of the CHIRPS satellite rainfall estimates over eastern of Africa. QJR Meteorol. Soc, 144: 292-312

Fiwa L, Vanuytrecht E, Wiyo KA, Raes D (2014). Effect of rainfall variability on the length of the crop growing period over the past three decades in central Malawi. Climate Research, 62(1): 45-58

Funk CC, Peterson PJ, Landsfeld MF, Pedreros DH, Verdin JP, Rowland JD, Verdin AP (2014) A quasi-global precipitation time series for drought monitoring. US Geological Survey data series, 832(4): 1-12

Gan TY (1995) Trends in air temperature and precipitation for Canada and north-eastern USA. International Journal of Climatology, 15(10): 1115-1134 
Gebre H, Kindie T, Girma M, Belay K (2013) Trend and variability of rainfall in Tigray, northern Ethiopia: analysis of meteorological data and farmers' perception. Academia Journal of Agricultural Research, 1(6): 088-100

Gebrehiwot T, van der Veen A, Maathuis (2011) Spatial and Temporal Assessment of Drought in the Northern Highlands of Ethiopia. Journal of Applied Earth Observation and Geoinformation 13: 309-321

Gebrehiwot T, van der Veen A (2013) Assessing the evidence of climate variability in the northern part of Ethiopia. Journal of Development and Agricultural Economics, 5(3): 104-119

Gebremicael TG, Mohamed YA, Hagos EY (2017) Temporal and spatial changes of rainfall and streamflow in the Upper Tekezē-Atbara river basin, Ethiopia. Hydrology and Earth System Sciences, Apr 19; 21(4):2127-42.

Gebreselassie MG, Moges SA (2016) Spatial and temporal variability of dry spell lengths and indication of climate change in rainfall extremes at Tekeze River Basin, Ethiopia. International Journal of Water Resources and Environmental Engineering, 8(3): 39-51

Gebreyohannes T, De Smedt F, Walraevens K, Gebresilassie S, Hussien A, Hagos M, Amare K, Deckers J, Gebrehiwot K (2010) Application of a spatially distributed water balance model for assessing surface water and groundwater resources in the Geba basin, Tigray, Ethiopia. Journal of Hydrology. 2013 Aug 30;499:11023

Hamza FM, Saimi FM Jaafar O (2017) Identifying the Monotonic Trend in Climate Change Parameter in Kluang and Senai, Johor, Malaysia. Sains Malaysiana, 46(10): 1735-1741

Hayelom B, Chen Y, Marsie Z, Negash M (2017) Temperature and precipitation trend analysis over the last 30 years in Southern Tigray Regional State, Ethiopia. Journal of Atmospheric Pollution, 5(1): 18-23

Jhajharia D, Dinpashoh Y, Kahya E, Choudhary RR, Singh VP (2014) Trends in temperature over Godavari river basin in southern peninsular India. International Journal of Climatology, 34(5): 1369-1384

Kendall M (1975) Rank Correlation Measures; Charles Griffin. London, 202p

Kiros G, Shetty A, Nandagiri L (2017) Extreme rainfall signatures under changing climate in semi-arid northern highlands of Ethiopia. Cogent Geoscience, 3(1): 1353719

Knapp KR, Ansari S, Bain CL, Bourassa MA, Dickinson MJ, Funk C, Kossin JP (2011) Globally gridded satellite observations for climate studies. Bulletin of the American Meteorological Society, 92(7): 893-907

Machiwal D, Jha MK (2008) Comparative evaluation of statistical tests for time series analysis: application to hydrological time series/Evaluation comparative de tests statistiques pour l'analyse de séries temporelles: application à des séries temporelles hydrologiques. Hydrological Sciences Journal, 53(2): 353-366

Mann H (1945) Nonparametric Tests against Trend. Mantua, NJ, SR Hare, Y. Zhang, JM Wallace, and RC Francis (1997), Econometrics 13: 245-259

Mekasha A, Tesfaye K, Duncan AJ (2014) Trends in daily observed temperature and precipitation extremes over three Ethiopian eco-environments. International Journal of Climatology, May;34(6):1990-9

Meles K, Maria A, Tesfamichael N, Sunil S, Francis K, Lynne M (1997) Coping with low and erratic rainfall in the Eastern zone of Tigray, Ethiopia

Meze-Hausken E (2004) Contrasting climate variability and meteorological drought with perceived drought and climate change in northern Ethiopia. Climate research, 27(1):19-31 
Muchuru S, Botai JO, Botai CM, Landman WA, Adeola AM (2016) Variability of rainfall over Lake Kariba catchment area in the Zambezi river basin, Z imbabwe. Theoretical and applied climatology, 124(1-2):325338

NMA (2007) Climate Change National Adaptation Programme of Action (Napa) Of Ethiopia. Addis Ababa, Ethiopia: The Federal Democratic Republic of Ethiopia Ministry of Water Resources, National Meteorological Agency

Nyssen J, Clymans W, Descheemaeker K, Poesen J, Vandecasteele I, Vanmaercke M, Zenebe A, Van Camp M, Haile M, Haregeweyn N, Moeyersons J (2010) Impact of soil and water conservation measures on catchment hydrological response - a case in north Ethiopia. Hydrological processes. 2010 Jun 30;24(13):1880-95

Palaniswami S, Muthiah K (2018). Change Point Detection and Trend Analysis of Rainfall and Temperature Series over the Vellar River Basin. Polish Journal of Environmental Studies, 27(4)

Parry M, Canziani OF, Palutikof J, van der Linden P, Hanson C (2007) Summary for policy makers. in: Climate Change 2007: Impacts, Adaptation and Vulnerability, Contribution of Working Group II to the Fourth Assessment Report of the Intergovernmental Panel on Climate Change. Cambridge, UK and New York: Cambridge University Press

Samo SR, Bhatti N, Saand A, Keerio MA, Bangwar DK (2017) Temporal Analysis of Temperature and Precipitation Trends in Shaheed Benazir Abad Sindh, Pakistan

Seleshi Y, Camberlin P (2006) Recent changes in dry spell and extreme rainfall events in Ethiopia. Theoretical and Applied Climatology, 83(1-4):181-191

Seleshi Y, Zanke U (2004) Recent changes in rainfall and rainy days in Ethiopia. International Journal of Climatology: A Journal of the Royal Meteorological Society, 24(8):973-983

Sen PK (1968) Estimates of the regression coefficient based on Kendall's tau. Journal of the American Statistical Association 63:1379-1389

Shapiro SS, Wilk MB. An analysis of variance test for normality (complete samples). Biometrika. 1965 Dec 1;52(3/4):591-611.

Sivakumar MVK (1992) Empirical analysis of dry spells for agricultural applications in West Africa. Journal of Climate, 5(5):532-539

Suryadi Y, Sugianto D N (2018) Climate Change In Indonesia (Case Study: Medan, Palembang, Semarang). In E3S Web of Conferences, 31:09-017

Tesfay GG, Yasir AM, Pieter van der Z, Amdom G, Gebremedhin G, Eyasu Y, Mulubirhan K (2019) Evaluation of multiple satellite rainfall products over the rugged topography of the Tekeze-Atbara basin in Ethiopia, International Journal of Remote Sensing, DOI: 10.1080/01431161.2018.1562585

Viste E, Korecha D, Sorteberg A (2012) Recent drought and precipitation tendencies in Ethiopia. Theor. Appl. Climatol. DOI 10.1007/s00704-012-0746-3

Weldesenbet GA (2019) Analysis of Rainfall Variability for Mekelle Meteorological Station, Northern Ethiopia (1960-2009) 